University of Nebraska - Lincoln

DigitalCommons@University of Nebraska - Lincoln

6-2005

\title{
Establishing Native Grasses in a Big Sagebrush-Dominated Site: An Intermediate Restoration Step
}

Elisabeth Huber-Sannwald

Utah State University, ehs@ipicyt.edu.mx

David A. Pyke

USGS Forest and Rangeland Ecosystem Science Center, david_a_pyke@usgs.gov

Follow this and additional works at: https://digitalcommons.unl.edu/usgsstaffpub

Huber-Sannwald, Elisabeth and Pyke, David A., "Establishing Native Grasses in a Big Sagebrush-Dominated Site: An Intermediate Restoration Step" (2005). USGS Staff -- Published Research. 603.

https://digitalcommons.unl.edu/usgsstaffpub/603

This Article is brought to you for free and open access by the US Geological Survey at DigitalCommons@University of Nebraska - Lincoln. It has been accepted for inclusion in USGS Staff -- Published Research by an authorized administrator of DigitalCommons@University of Nebraska - Lincoln. 


\title{
Establishing Native Grasses in a Big Sagebrush-Dominated Site: An Intermediate Restoration Step
}

\author{
Elisabeth Huber-Sannwald ${ }^{1,2,3}$ and David A. Pyke ${ }^{4}$
}

\begin{abstract}
Many semiarid rangelands in the Great Basin, U.S.A., are shifting dominance to woody species as a consequence of land degradation including intense livestock grazing and fire suppression. Whereas past rehabilitation efforts in Big sagebrush (Artemisia tridentata) steppes removed the shrub and added introduced forage grasses to successfully shift communities from shrublands to grasslands, current consensus is that native species should be included in restoration projects and that retention of some woody plants is desirable. We examined the potential for interseeding grasses into dense shrub communities as a precursor to thinning shrubs and releasing grasses from shrub interference. We compared seedling establishment of the native grass, Bluebunch wheatgrass (Pseudoroegneria spicata), with that of the Eurasia grass, Crested wheatgrass (Agropyron desertorum), in dense Ar. tridentata stands. Shrubs may play an important role as nurse plants for seedling establishment (reduced solar radiation, "island of fertility" effect) but result in highly contrasting light environments and root interference for seedlings. In experimental plots, we examined effects of $A r$. tridentata shade levels $(0,40,70$, and $90 \%$ reduction of solar radiation) and initial root exclusion (present/absent) on the establishment and growth of $\boldsymbol{P}$. spicata and $\mathrm{Ag}$. desertorum seedlings. With this design we evaluated the interference effects of
\end{abstract}

Ar. tridentata on the two grasses and identified the most beneficial microsites for grass restoration in Ar. tridentatadominated communities. We predicted seedling survival and growth to be greater under moderate shade $(40 \%$ reduction) and limited root competition than under no or strong shade conditions ( 0 and $90 \%$ ) and unrestricted root interactions. Fifty to $85 \%$ of the $P$. spicata and $\mathrm{Ag}$. desertorum seedlings survived the dry summer months of 1995 and 1996 and the intervening winter. Neither shading nor root exclusion from Ar. tridentata affected final seedling survival of either species. Seedling biomass of both grass species was negatively affected by initial root interactions with Ar. tridentata. However, the analysis of seedling biomass variability (coefficient of variation) indicated that in all shade and root-exclusion treatments, some seedlings of both species developed to large individuals to survive in Ar. tridentata-dominated rangelands. Thus, the use of interseeding techniques shows promise for restoring herbaceous species in dense $A r$. tridentata stands and should be given further consideration when shrub retention is an important consideration.

Key words: Agropyron desertorum, Artemisia tridentata, degraded rangelands, native and introduced grass species, Pseudoroegneria spicata, restoration, shoot and root interference, survival.

\section{Introduction}

Under pre-settlement conditions, Big sagebrush (Artemisia tridentata (Nutt.)) and perennial tussock grasses, such as the widespread Bluebunch wheatgrass (Pseudoroegneria spicata (Pursh) A. Löve), codominated undisturbed sagebrush steppe communities (West 1991). Many semiarid plant communities in the Great Basin, U.S.A., are shifting to woody species dominance as a consequence of land degradation. The degradation is a consequence of both intense cattle grazing and fire suppression. Heavy grazing of grasses late in the growing season reduced the

${ }^{1}$ Rangeland Resources Department, Utah State University, Logan, UT 84322-5230, U.S.A.

${ }^{2}$ Instituto Potosino de Investigación Científica y Tecnológica, Camino a la Presa San José 2055, San Luis Potosí, SLP 78216, Mexico.

${ }^{3}$ Address correspondence to E. Huber-Sannwald, email ehs@ipicyt.edu.mx

${ }^{4}$ USGS Forest and Rangeland Ecosystem Science Center, Corvallis, OR 97331, U.S.A.

presence of grass in Ar. tridentata communities (Stoddart 1946; Young et al. 1977; West 1983) and removed the main source of continuous fuel for fires. When combined with the intentional suppression of fires, this overgrazing resulted in increase in dominance of species sensitive to fires and not preferred as forage for livestock, such as Ar. tridentata (Archer et al. 1988; Archer 1994; Miller et al. 1994; Van Auken 2000).

Sagebrush dominance was typical in the Great Basin during the 1950s when the Bureau of Land Management instituted programs to reduce sagebrush through herbicide applications and to rehabilitate lands by seeding introduced forage grasses such as the introduced tussock grass, Crested or Desert wheatgrass (Agropyron desertorum (Fisch. Ex Link) Schult. or Ag. cristatum (L.) Gaertn.) (Heady 1988). Thus, directed revegetation was considered necessary to reverse the transition to woody species dominance and to reintroduce tussock grasses into the ecosystem (Robertson 1971; Sanders \& Voth 1983; West et al. 1984). 
Restoration of a diverse set of native plants is advocated to maintain a functioning ecosystem that provides forage and cover for a wide range of wildlife species. Some species, like the Greater Sage Grouse (Centrocercus urophasianus), require a mixture of sagebrush, grasses, and forbs for their survival (Crawford et al. 2004). Typical restoration plans in sagebrush grasslands call for the removal of shrubs to prepare for seeding herbaceous species using a rangeland seed drill (Vallentine 1989). We were interested in the potential of establishing tussock grasses directly into dense stands of sagebrush before applying treatments to reduce sagebrush densities and release grasses from interference for light and soil resources.

Artemisia tridentata may play a pivotal role for grass seedling establishment as nurse plants that reduce solar radiation and soil temperature and increase soil moisture and soil nutrient availability (Garcia-Moya \& McKell 1970; Doescher et al. 1984; Schlesinger et al. 1990; Callaway 1995; Callaway et al. 1996; Chambers \& Linnerooth 2001; Castro et al. 2002, 2004). Higher concentrations of soil organic matter beneath shrubs also may increase water-holding capacity and water retention. In addition, Ar. tridentata has been shown to move water vertically from deep to shallow soil depths via hydraulic lift (Caldwell \& Richards 1989). Although mature grass neighbors do not require this water, they can access it (Caldwell 1990). Other species have shown beneficial responses from neighboring plant water (Caldwell et al. 1998), but to our knowledge, no one has examined seedling survival. Yet, hydraulically lifted water is also a limiting resource for which Ar. tridentata may compete for with understory plants (Campbell \& Harris 1977).

Our major objective was to determine survival and growth of P. spicata and $A g$. desertorum seedlings in the vicinity of $A r$. tridentata and to examine if potential positive effects of shrubs on survival and growth may be counterbalanced by simultaneous adverse effects of shade and/ or root interference for resources. We examined establishment and growth of seedling populations of the two grass species under different light levels $(0,40,70$, and $90 \%$ reduction of solar radiation) consisting of a combination of natural (beneath shrub canopy) and artificial (shade cloth) shade treatments in the vicinity of Ar. tridentata shrubs. We also evaluated how early belowground interference between the shrub and grass seedlings influenced these responses. We predicted that seedling survival and growth would be highest in treatments with intermediate shade and would decline with increasing and decreasing light availability. Further, we predicted that seedling survival and growth would be highest when roots of Ar. tridentata were excluded during the early phases of seedling establishment and growth.

\section{Methods}

This field experiment was conducted in 5-year-old Artemisia tridentata experimental plots near Logan, Utah (lat $41^{\circ} 45^{\prime} \mathrm{N}$, long $111^{\circ} 48^{\prime} \mathrm{W} ; 1,460 \mathrm{~m}$ a.s.l.). Plots consisted of a mixture of pure and hybrid forms of $A$. $t$. ssp. vaseyana (Rydb.) Beetle and tridentata Nutt., a common occurrence in foothill environments where both subspecies coexist (McArthur et al. 1988). The mean annual temperature in Logan, Utah, is approximately $8^{\circ} \mathrm{C}$, and the mean daily maximum temperature is $31^{\circ} \mathrm{C}$. Mean annual precipitation is $468 \mathrm{~mm}$, with $75 \mathrm{~mm}$ falling in the summer months.

The distance between Ar. tridentata plants was approximately $50 \mathrm{~cm}$ in three blocks that captured the soil variation of the field location. On the north and south side of the shrubs (60-70 $\mathrm{cm}$ tall) eight grass seedling populations were planted in one of a combination of four shade and two root-exclusion treatments.

\section{Shade Treatment}

Artemisia tridentata plants vary in size and leaf density, and solar radiation may be considerably attenuated while passing through the shrub canopy. This results in reduced light availability beneath shrubs, especially on the north side of shrubs. By combining natural and artificial shade treatments, we established a "light gradient" consisting of $0,40,70$, and $90 \%$ shade (light reduction) to simulate high- to low-light environments typically found in stands with different shrub densities. The south and north side of shrubs provided natural light treatments: south side $0 \%$ shade, north side $40 \%$ shade. To enhance light reduction beneath shrub canopies, as occurs in taller Ar. tridentata communities, artificial shade treatments were applied on the southwest side of shrubs $(70 \%$ shade) and on the northwest side ( $90 \%$ shade). The gradient in photon flux density (PFD; $\mu \mathrm{mol}$ photons $\mathrm{m}^{-2} \mathrm{~s}^{-1}$ ) ranged from approximately $1,500(0 \%$ shade $)$ to $120(90 \%$ shade $) \mu \mathrm{mol}$ photons $\mathrm{m}^{-2} \mathrm{~s}^{-1}$ when measured at the four locations around shrubs at noon on several sunny days in May and September 1994 with a quantum sensor (LI-COR, Lincoln, Nebraska, U.S.A.) held horizontally on the soil surface. We chose shrubs of equal size to maintain similar light gradient conditions. Even though light conditions change throughout the growing season, the proportion of light reduction along the light gradient was maintained throughout the experiment. Any Ar. tridentata plant growing south of the target sagebrush that might cast a shadow on seeded grasses was tied back to eliminate shading. Artificial shade consisted of a combination of shade cloth and shade film that reduced PFD intensity but maintained the spectral composition of light typically found beneath canopies. The film consisted of a clear Mylar plastic covered with one sheet of window tint (3M Scotchtint Window Film NR20SMALL); it was sandwiched between two layers of standard chicken wire for support. The artificial shade formed a 40-cm-high half-cylinder around the west, south, and east side of a pair of grass seedling populations planted in root-exclusion tubes (see below) on the north and south side of the shrub. The shade construction remained open toward the north to minimize additional 
microclimatic effects (e.g., temperature or wind) that could influence seedling growth. The shade construction provided morning and afternoon shade and partial sun exposure during noon in early May, the time of active growth. The artificial shade reduced the red:farred (R:FR) ratio from 1.03 in sunlight to $0.43-0.44$ (measured with a Sky 660/730 sensor). Shading was removed during the winter months to avoid snow accumulation and altered freezing/thawing events.

\section{Root-Exclusion Treatment}

Root-exclusion tubes of different lengths make it possible to study the effects of early root interaction between adult plants and seedlings without having to remove competitors or to establish root trenches (Cook \& Ratcliff 1984; Reichenberger \& Pyke 1990). In fall 1994, two pairs of thin-walled polyvinyl chloride (PVC) tubes (3-mm thick) of two lengths ( 1 and $10 \mathrm{~cm} ; 10-\mathrm{cm}$ diameter) were pressed into the soil until the upper rim of the tube was flush with the surface and $20 \mathrm{~cm}$ from the stem of the target shrub. The distance between tubes in each pair was 4 $\mathrm{cm}$. Because root density is highest in the upper $15 \mathrm{~cm}$ of the soil (Caldwell \& Richards 1986), the 10-cm tubes provided root exclusion of neighboring $A r$. tridentata plants during early seedling growth (Reichenberger \& Pyke 1990). The root-exclusion tubes inhibited early competition between seedlings and adult shrubs but did not completely eliminate all potential positive or negative root effects of $A r$. tridentata (redistribution of hydraulically lifted water, root exudation, etc.). PVC tubes did constrain horizontal water and nutrient flow in the upper soil layer. The 1-cm tubes served as controls where roots of grass seedlings interacted with those of neighboring Ar. tridentata, but inadvertent side effects of precipitation accumulation were similar among tube depths. In summer 1994, before root-exclusion tubes were inserted into the soil, $780 \mathrm{~cm}^{3}$ of soil (the dimensions of the 10-cm-long tube) was excavated and sieved to eliminate rocks greater than $2 \mathrm{~cm}$ at each tube location. In a preliminary study, many seedlings died in root-exclusion tubes because large rocks inhibited seedling roots from accessing water beneath tubes. The sieved soil (including root material) was then used to refill the holes.

In fall 1994, 30 seeds of Pseudoroegneria spicata or Agropyron desertorum were sown into each tube. After germination, seedlings were thinned to 15 similar-sized individuals per tube, giving a density of about 1,900 seedlings $/ \mathrm{m}^{2}$. The density is similar to usual densities for $\mathrm{Ag}$. desertorum but may be higher than natural densities for P. spicata (Pyke 1990). Each seedling within a tube was marked with a different colored wire hoop in April 1995 and monitored throughout the study. Seedlings emerging later were removed. Seedlings were monitored monthly for survival from April until October 1995 and from April until June 1996. In July 1996, shoots of each seedling were harvested by clipping at the soil surface; seedlings were then dried for 2 days at $70^{\circ} \mathrm{C}$, and each individual seedling was weighed. We determined the coefficient of variation (CV) for mass of individual seedlings in each tube to detect whether seedling size was homogeneous or whether some treatments yielded clear differences in seedling size within a population. Before harvest, we measured shoot height of the tallest tiller from the base to the insertion of the youngest leaf blade for each seedling. We determined mean tiller height and $\mathrm{CV}$ of height for seedling populations per tube.

\section{Statistical Analysis}

The experimental design was a randomized complete block, split-split plot design, with three replicated Ar. tridentata plots as blocks (wholeplots). There were three experimental units: block, location, and tube. In each block, there were three subsamples of randomly chosen shrubs for each grass species. The grass species were assigned to randomly chosen shrubs in the block subsamples. Each shrub contained all levels of each of two treatments, shade and root exclusion. Each shade level was split by the two root-exclusion levels. Subsample means were used in analyses. Analyses were conducted separately for each grass species. Individual seedling shoot biomass, maximum shoot biomass, shoot height, CV for biomass and height, and final seedling survival (\%) were analyzed with the mixed procedure in SAS release 6.1 (SAS 1996). All variables were tested for normality with box plots and normal probability plots of residuals. Based on these tests, none of the variables had to be transformed. The data are presented as least square means $( \pm \mathrm{SE})$ or model estimates from the mixed procedure. We conducted mean comparison tests for significant main and interaction effects using Bonferroni-adjusted $p$ values. Survival analysis was conducted with the LIFETEST procedure. We also conducted multiple comparison tests of survival curves using the Wilcoxon rank statistic (Fox 2001).

\section{Results}

\section{Survival}

The highly contrasting light conditions in dense Artemisia tridentata communities did not affect the final survival of Pseudoroegneria spicata seedlings after the 20 months of the study (Fig. 1 ; shade main effect, $F_{[3,6]}=1.86 ; p=$ 0.23 ); however, there was some indication that seedling survival was lower with the two highest levels of shade. Fifty to $85 \%$ of the seedlings survived the three seasons: the dry summer months of 1995 and 1996 and the intervening winter period of 1995/1996. Early root interaction with $A r$. tridentata did not influence final survival of $P$. spicata seedlings in any of the shade levels (Fig. 1; rootexclusion main effect, $\left.F_{[1,8]}=0.54 ; p>0.48\right)$. Survival of P. spicata seedlings from 21 April 1995 until 1 July 1996 was affected by shade levels and root exclusion (Fig. 2; log-rank test $\left.\chi^{2}=42.56, d f=7 ; p<0.001\right)$. During the dry 


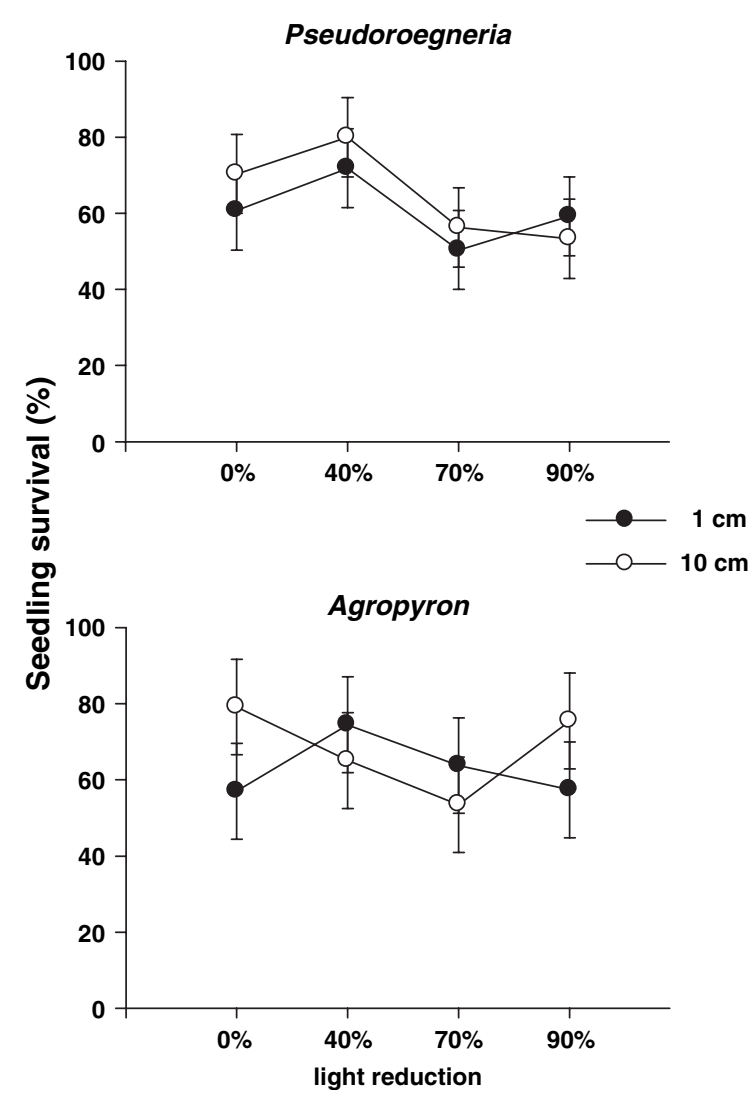

Figure 1. Least squares means $( \pm \mathrm{SE})$ of survival (\%) of Pseudoroegneria spicata (top) and Agropyron desertorum (bottom) seedlings by July 1996 in response to different shade (light reduction $0,40,70$, and $90 \%$ ) and root exclusion ( $1 \mathrm{~cm}=$ roots of Artemisia tridentata always present, $10 \mathrm{~cm}=$ roots of Artemisia absent at early stage) treatments.

period from May to August 1995, the survival rate was clearly higher for seedlings exposed to full light and moderate light conditions compared to seedlings under strong shade conditions (70 and $90 \%$ light reduction) where approximately $20-35 \%$ of the $P$. spicata seedlings died (Table 1: comparison $10 \mathrm{~cm}-0$ vs. $70 \% ; 10 \mathrm{~cm}-40$ vs. $70 \% ; 10 \mathrm{~cm}-40$ vs. $90 \%$; Fig. 2). However, in May and June 1995 the survival rate was only low for those seedlings not interacting with $A r$. tridentata, whereas by the end of July 1995 all populations under dense shade had lost $30 \%$ of their seedlings (Table $1: 90 \%-1$ vs. $10 \mathrm{~cm}$; Fig. 2). Fall and winter of 1995/1996 hardly affected seedling survivorship; in May and July 1996, 5-10\% of the seedlings died (Fig. 2).

Agropyron desertorum emerged as seedlings much earlier in spring (March) 1995 than did P. spicata. However, most of these seedlings died early due to frost heaving and subsequent desiccation of their exposed roots. Neither treatment affected the early mortality of $\mathrm{Ag}$. desertorum seedlings. Thus, the initial density of seedling populations of $\mathrm{Ag}$. desertorum consisted on average of 11 seedlings (instead of 15). The percentage of surviving Ag. desertorum seedlings by July 1996 was not affected by shade or



Figure 2. Survivorship curves of Pseudoroegneria spicata (top) and Agropyron desertorum (bottom) seedlings in response to different shade (light reduction $0,40,70$, and $90 \%$ ) and root exclusion $(1 \mathrm{~cm}=$ roots of Artemisia tridentata always present, $10 \mathrm{~cm}=$ roots of Artemisia absent at early stage) treatments over a 20-month time period.

by early root exclusion of $A r$. tridentata (Fig. 1; shade main effect, $F_{[3,6]}=0.50, p<0.50$; root-exclusion main effect, $\left.F_{[1,8]}=0.96 ; p<0.36\right)$. Survival rate of Ag. desertorum seedlings over the 338 days was influenced by both shade and root exclusion of Ar. tridentata (Fig. $2 ; \chi^{2}=52.02 ; p<$ 0.0001 ). The lowest survival rates occurred between May and July 1995 and 1996. Under shade-free conditions, seedling interactions with $A r$. tridentata roots had the most negative effect on seedling survival (Table 1: $0 \%-1$ vs. 10 $\mathrm{cm}$; Fig. 2). A similar root-exclusion response occurred under the highest shade level (Table 1: $90 \%-1$ vs. $10 \mathrm{~cm}$; Fig. 2). When interacting with $A r$. tridentata roots and moderate shading significantly benefited seedling survival rate (Table 1: $1 \mathrm{~cm}-0$ vs. $40 \%$ ), especially in the second year.

\section{Biomass}

Although early root exclusion did not affect the survival of $P$. spicata seedlings, it resulted in higher mean shoot 
Table 1. Multiple comparison of survivorship curves for Pseudoroegneria spicata and Agropyron desertorum seedlings based on Wilcoxon rank statistics with adjusted $Z$ values.

\begin{tabular}{|c|c|c|c|c|}
\hline & \multicolumn{2}{|c|}{$\begin{array}{l}\text { Pseudoroegneria } \\
\text { spicata }\end{array}$} & \multicolumn{2}{|c|}{$\begin{array}{l}\text { Agropyron } \\
\text { desertorum }\end{array}$} \\
\hline & $Z$ & $p<$ & $Z$ & $p<$ \\
\hline \multicolumn{5}{|l|}{ Root-exclusion effect } \\
\hline $0 \%-1$ vs. $10 \mathrm{~cm}$ & 1.2272 & 0.220 & 5.7882 & 0.001 \\
\hline $40 \%-1$ vs. $10 \mathrm{~cm}$ & 1.3386 & 0.181 & 0.8502 & 0.395 \\
\hline $70 \%-1$ vs. $10 \mathrm{~cm}$ & 0.0176 & 0.986 & 0.9043 & 0.366 \\
\hline $90 \%-1$ vs. $10 \mathrm{~cm}$ & 1.9662 & 0.049 & 3.4424 & 0.001 \\
\hline \multicolumn{5}{|l|}{ Shade effect } \\
\hline \multicolumn{5}{|c|}{ Without root exclusion } \\
\hline $1 \mathrm{~cm}-0$ vs. $40 \%$ & 1.4938 & 0.135 & 3.2662 & 0.001 \\
\hline $1 \mathrm{~cm}-0$ vs. $70 \%$ & 1.7151 & 0.086 & 1.6478 & 0.100 \\
\hline $1 \mathrm{~cm}-0$ vs. $90 \%$ & 0.1998 & 0.842 & 1.3762 & 0.169 \\
\hline $1 \mathrm{~cm}-40$ vs. $70 \%$ & 3.2214 & 0.001 & 1.6162 & 0.106 \\
\hline $1 \mathrm{~cm}-40$ vs. $90 \%$ & 1.6917 & 0.091 & 1.7748 & 0.076 \\
\hline $1 \mathrm{~cm}-70$ vs. $90 \%$ & 1.5112 & 0.131 & 0.2129 & 0.831 \\
\hline \multicolumn{5}{|l|}{ With root exclusion } \\
\hline $10 \mathrm{~cm}-0$ vs. $40 \%$ & 1.6077 & 0.108 & 1.6597 & 0.097 \\
\hline $10 \mathrm{~cm}-0$ vs. $70 \%$ & 2.9829 & 0.003 & 3.4961 & 0.001 \\
\hline $10 \mathrm{~cm}-0$ vs. $90 \%$ & 3.4237 & 0.001 & 0.6623 & 0.510 \\
\hline $10 \mathrm{~cm}-40$ vs. $70 \%$ & 4.6112 & 0.001 & 1.7588 & 0.079 \\
\hline $10 \mathrm{~cm}-40$ vs. $90 \%$ & 5.0340 & 0.001 & 0.9476 & 0.343 \\
\hline $10 \mathrm{~cm}-70$ vs. $90 \%$ & 0.4702 & 0.638 & 2.6914 & 0.007 \\
\hline
\end{tabular}

Shade treatments are light reduction: $0,40,70$, and $90 \%$; root-exclusion treatments are $1 \mathrm{~cm}=$ Artemisia tridentata roots always present, $10 \mathrm{~cm}=$ Artemisia roots absent at early stage.

biomass of seedlings regardless of shade levels (Fig. 3; root-exclusion main effect, $\left.F_{[1,8]}=109.31 ; p<0.001\right)$. The different shade conditions did not affect seedling biomass (Fig. 3; shade main effect, $F_{[3,6]}=3.13 ; p<0.12$ ). Overall, the $\mathrm{CV}$ of seedling mass in populations was greater when seedlings competed with Ar. tridentata roots compared to limited root interaction (Fig. 4; root-exclusion main effect, $\left.F_{[1,8]}=5.63 ; p<0.04\right)$. This suggests that only a few seedlings developed into large individuals when competing with $A r$. tridentata. The largest mean seedling biomass occurred in the early root-exclusion treatment (Table 2; root-exclusion main effect, $F_{[1,8]}=35.8 ; p<0.0003$ ), and shading did not affect maximum seedling size (Table 2; $\left.F_{[3,6]}=1.86 ; p<0.24\right)$.

For Ag. desertorum, only early root exclusion decreased mean seedling mass (Fig. 3; root-exclusion main effect, $\left.F_{[1,8]}=7.93 ; p<0.02\right)$, whereas the different shade conditions had no effect (Fig. 3; shade main effect, $F_{[3,6]}=7.93$; $p<0.41$ ). The $\mathrm{CV}$ for individual seedling mass was high, yet it was not influenced by root exclusion of Ar. tridentata or shade conditions (Fig.4; root-exclusion main effect, $F_{[1,8]}=0.16 ; p>0.7$; shade main effect, $F_{[3,6]}=2.82 ; p<$ $0.13)$. However, there was some indication that the CV of seedling mass was higher in the $90 \%$ light reduction treatment compared to the 40 and $70 \%$ reduction treatments (shade $\times$ root exclusion interaction, $F_{[3,8]}=2.35 ; p<$ $0.15)$. Neither the root exclusion nor the shade treatments affected mean maximum seedling size (Table2; root- exclusion main effect, $F_{[3,6]}=0.60 ; p<0.92$; shade main effect, $\left.F_{[1,8]}=0.01 ; p<0.64\right)$.

\section{Shoot Morphology}

Like mean shoot biomass of $P$. spicata seedlings, mean shoot height was greater when roots of Ar. tridentata were excluded (Fig. 5; root-exclusion main effect, $F_{[1,8]}=21.95$; $p<0.002)$. The different shade conditions did not affect seedling height (Fig. 5; shade main effect, $F_{[3,6]}=3.01 ; p<$ 0.12 ), although with increasing shade, height seemed elongated. The CV of mean height was around $30 \%$ for all shade and root-exclusion treatments (Fig. 6; shade main effect, $F_{[3,6]}=2.14 ; p<0.20$; root-exclusion main effect, $\left.F_{[1,8]}=2.33 ; p<0.16\right)$.

Agropyron desertorum seedlings were shorter when exposed to roots of $A r$. tridentata than when roots were excluded (Fig. 5; root-exclusion main effect, $F_{[1,8]}=18.37$; $p<0.003)$. Seedlings growing under strong shade (70 and $90 \%$ ) were on average $4 \mathrm{~cm}$ taller than unshaded and moderately shaded (40\%) seedlings (Fig. 5; shade main effect, $\left.F_{[3,6]}=19.34 ; p<0.002\right)$. The $\mathrm{CV}$ of height for $\mathrm{Ag}$. desertorum seedlings was similar (approximately $40 \%$ ) for all combinations of root exclusion and shade

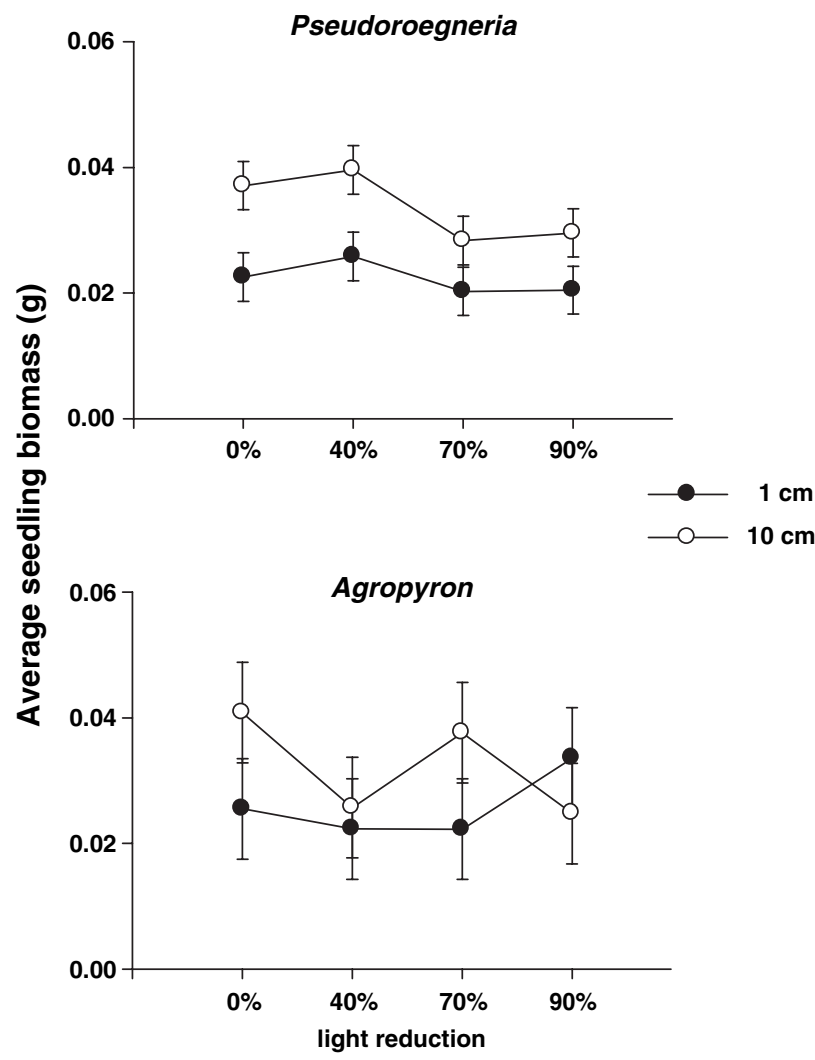

Figure 3. Least squares means $( \pm \mathrm{SE})$ of shoot biomass $(\mathrm{g})$ of Pseudoroegneria spicata (top) and Agropyron desertorum (bottom) seedlings in response to different shade (light reduction $0,40,70$, and $90 \%$ ) and root exclusion ( $1 \mathrm{~cm}=$ roots of Artemisia tridentata always present, $10 \mathrm{~cm}=$ roots of Artemisia absent at early stage) treatments. 
(Fig. 6; root-exclusion main effect, $F_{[1,8]}=1.07 ; p<0.33$; shade main effect, $\left.F_{[3,6]}=1.22 ; p<0.38\right)$.

\section{Discussion}

The area in the immediate vicinity of Artemisia tridentata shrubs presents a number of potentially favorable and adverse microsites for seedling establishment. Highly contrasting light environments on the south or north side of shrubs and the high soil resource availability beneath shrubs could both enhance (less heat stress, more soil resources) and hamper (insufficient irradiance, root exclusion between seedlings and shrub) seedling success. The use of shrubs as nurse plants is a useful tool in revegetation efforts in desert, mediterranean, and mountain ecosystems (Callaway et al. 1996; Castro et al. 2002, 2004). Thus, identifying the positive and negative effects of the abundant Ar. tridentata shrubs in the Great Basin may prove extremely valuable for low-input restoration efforts to reestablish perennial grasses in near monocultures of Ar. tridentata. This may prove important considering the loss of Ar. tridentata in the region and its impact through
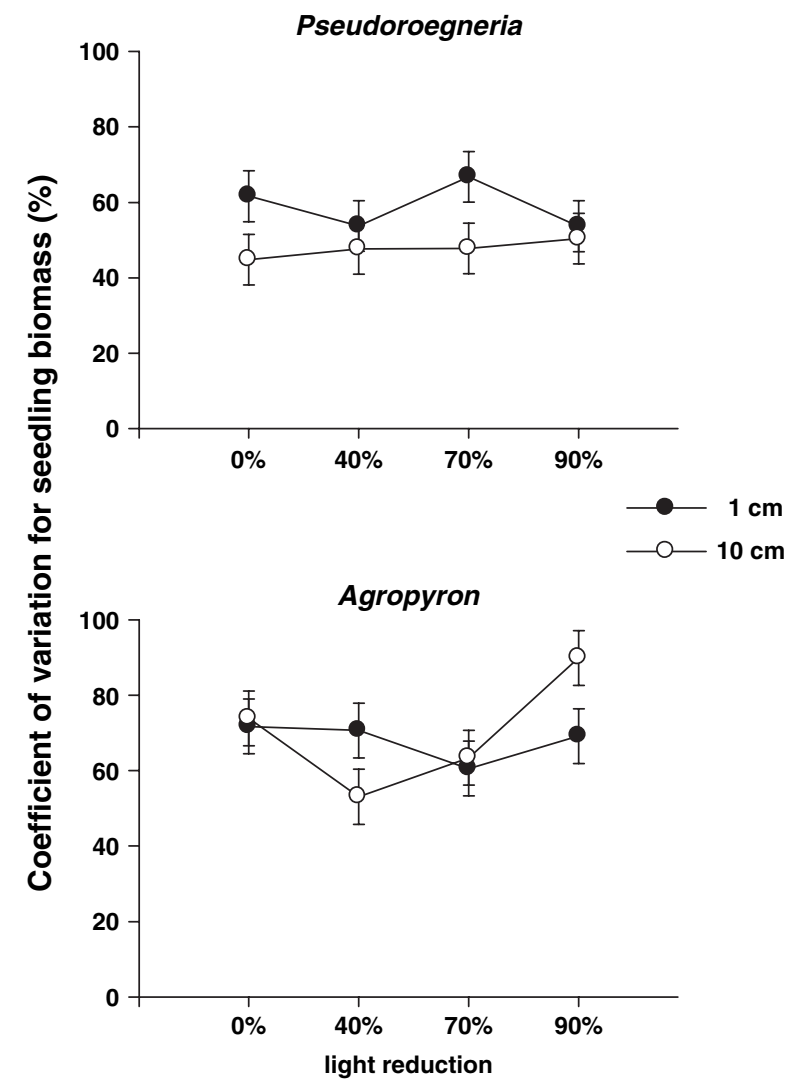

Figure 4. Least squares means $( \pm \mathrm{SE})$ of $\mathrm{CV}$ for shoot biomass $(\%)$ of Pseudoroegneria spicata (top) and Agropyron desertorum (bottom) seedlings in response to different shade (light reduction 0, 40, 70, and $90 \%$ ) and root exclusion ( $1 \mathrm{~cm}=$ roots of Artemisia tridentata always present, $10 \mathrm{~cm}=$ roots of Artemisia tridentata absent at early stage) treatments.
Table 2. Least squares means $( \pm \mathrm{SE})$ of mean maximum shoot biomass (g) of Pseudoroegneria spicata and Agropyron desertorum seedlings after 20 months of growth under different shade (light reduction $0,40,70$, and $90 \%)$ and root exclusion $(1 \mathrm{~cm}=$ roots of Artemisia tridentata present, $10 \mathrm{~cm}=$ roots of Artemisia absent at early stage) treatments.

\begin{tabular}{lccc}
\hline & & \multicolumn{2}{c}{ Treatments } \\
\cline { 3 - 4 } $\begin{array}{l}\text { Shade } \\
(\%)\end{array}$ & $\begin{array}{c}\text { Root } \\
\text { Exclusion }(\mathrm{cm})\end{array}$ & $\begin{array}{c}\text { Pseudoroegneria } \\
\text { spicata }\end{array}$ & $\begin{array}{c}\text { Agropyron } \\
\text { desertorum }\end{array}$ \\
\hline 0 & 1 & $0.027 \pm 0.006$ & $0.041 \pm 0.0142$ \\
0 & 10 & $0.043 \pm 0.006$ & $0.055 \pm 0.0140$ \\
40 & 1 & $0.034 \pm 0.006$ & $0.029 \pm 0.0142$ \\
40 & 10 & $0.056 \pm 0.006$ & $0.031 \pm 0.0142$ \\
70 & 1 & $0.034 \pm 0.006$ & $0.039 \pm 0.0142$ \\
70 & 10 & $0.043 \pm 0.006$ & $0.044 \pm 0.0142$ \\
90 & 1 & $0.024 \pm 0.006$ & $0.057 \pm 0.0142$ \\
90 & 10 & $0.042 \pm 0.006$ & $0.032 \pm 0.0142$ \\
\hline
\end{tabular}

trophic systems (Knick et al. 2003). Restoration techniques are needed that can retain the remaining Ar. tridentata while restoring the depleted herbaceous community. Establishing grasses in association with Ar. tridentata and then using techniques such as mosaic fires or low levels of herbicides to thin sagebrush might achieve this goal (Johnson et al. 1996; Wrobleski \& Kauffman 2003).

Contrary to our prediction, ultimate seedling survival of Pseudoroegneria spicata and Agropyron desertorum was not affected by root interference with $A r$. tridentata although timing of mortality in the first year was influenced. Survival of seedling populations of $P$. spicata and Ag. desertorum after 20 months was high in the relatively dense Ar. tridentata stands used for this study. On average, $75 \%$ of the seedlings of both grass species survived, indicating that the light gradient caused by the canopy and early root interference of $A r$. tridentata did not considerably affect the survival of either grass species. Evidence that seedling mortality in the first half of the experiment was not density dependent (intraspecific competition) is provided by the fact that seedlings with greater mean seedling biomass did not necessarily coincide with sparser populations. Factors associated with resource interference with $A r$. tridentata are more likely the explanation. The first months of the growing season in 1995 was the period when seedling survival of $P$. spicata was negatively affected at locations where irradiance was the lowest. The decline in seedling survival was only observed initially (May and June 1995) in the absence of early interaction with $A r$. tridentata roots, providing some indication of a negative nurse plant effect. By August 1995 the survival of all seedling populations exposed to 70 and $90 \%$ light reduction had declined to $70 \%$.

It was probably a combination of light reduction and early water scarcity that affected seedling survival in summer of 1995. Artemisia tridentata hydraulically lifts water from greater root depths and redistributes water to shallow soil (Caldwell \& Richards 1989), where it could 


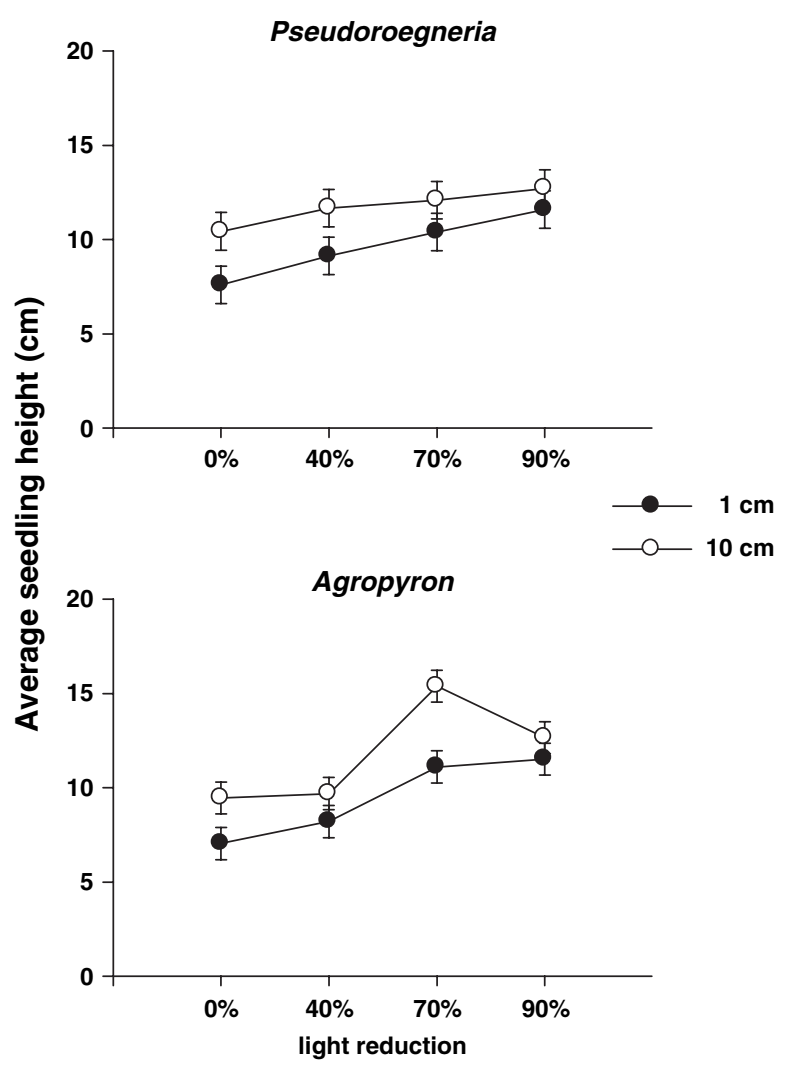

Figure 5. Least squares means $( \pm \mathrm{SE})$ of shoot height $(\mathrm{cm})$ of Pseudoroegneria spicata (top) and Agropyron desertorum (bottom) seedlings in response to different shade (light reduction $0,40,70$, and $90 \%)$ and root exclusion $(1 \mathrm{~cm}=$ roots of Artemisia tridentata always present, $10 \mathrm{~cm}=$ roots of Artemisia absent at early stage) treatments.

potentially become an important water source for seedlings growing beneath $A r$. tridentata canopies. Dawson (1996) has shown this phenomenon is important for small trees that do not access deep water. Although hydraulic lift may be important for grass seedlings establishment, Caldwell (1990) demonstrated that for mature forms of these grasses it is only minor. Further research would need to determine the role of hydraulic lift in seedling establishment.

In contrast, $A g$. desertorum seedling survival during the first months was negatively affected by early interactions with Ar. tridentata plants for almost all irradiance levels. This root interference effect on survival was most negative when seedlings were fully exposed to light. Survival was highest in the absence of early root interactions with $A r$. tridentata in both heavily shaded $(90 \%)$ and fully lightexposed grasses (0\%) (Fig. 2), suggesting that the survival of $\mathrm{Ag}$. desertorum seedlings is primarily affected by root interference with $A r$. tridentata.

In a previous field study (Reichenberger \& Pyke 1990), seedlings of the two grass species in the vicinity of Ar. tridentata ssp. vaseyana and Ar. tridentata ssp. wyomingensis shrubs died 3-5 months after the initiation of the experiment. This high mortality was probably caused by root competition between Ar. tridentata and the seedlings;
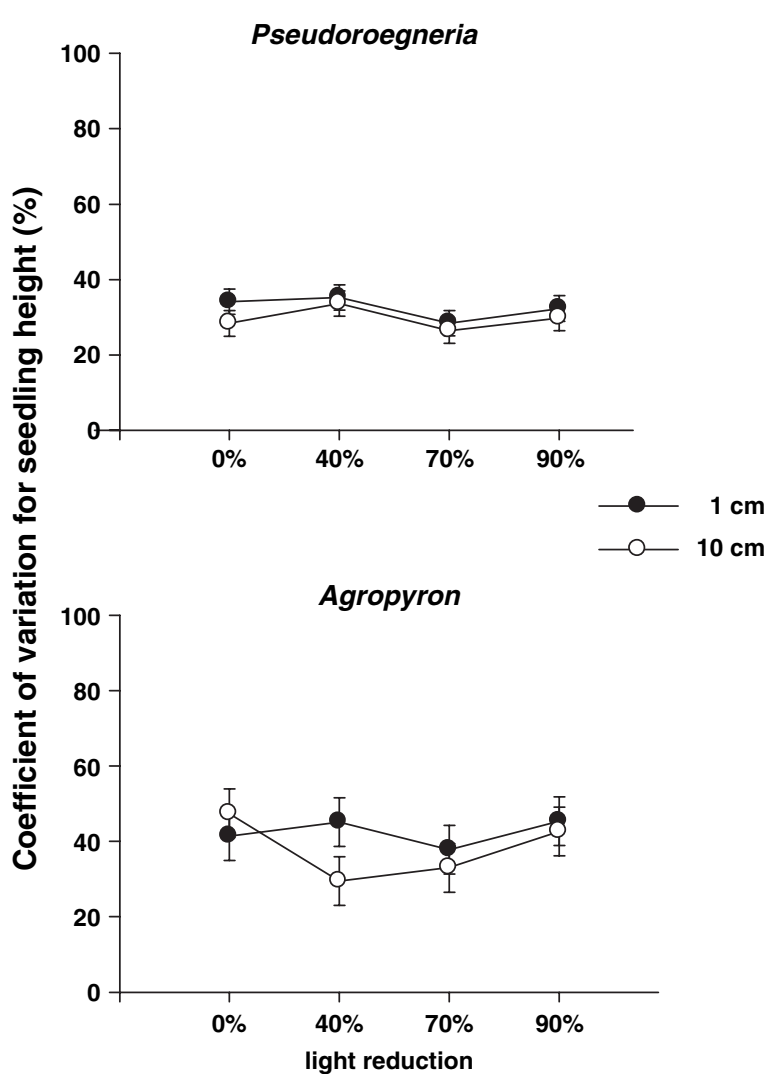

Figure 6. Least squares means $( \pm \mathrm{SE})$ of $\mathrm{CV}$ for shoot height (\%) of Pseudoroegneria spicata (top) and Agropyron desertorum (bottom) seedlings in response to different shade (light reduction $0,40,70$, and $90 \%)$ and root exclusion $(1 \mathrm{~cm}=$ roots of Artemisia tridentata always present, $10 \mathrm{~cm}=$ roots of Artemisia absent at early stage) treatments.

however, potential shading effects by Ar. tridentata on grass seedling performance were not examined. Similar to our study, early root interference decreased survival of $A g$. desertorum seedlings, whereas the survival of $P$. spicata seedlings was not directly affected by root interaction with shrubs. Seedling survival in semiarid deserts of the Intermountain Region is primarily influenced by water availability during the growing season. Soil moisture is usually high early in the growing season and becomes increasingly limiting during the summer months, coinciding with the commonly high and low survival rates of seedlings of perennial species in these seasons (Salihi \& Norton 1987; Pyke 1990; Reichenberger \& Pyke 1990). We observed somewhat contrasting patterns of seedling survival for Ag. desertorum whose seedling survival was lowest between the beginning of May and early July in both years, whereas between July and September (the driest months) almost all seedlings survived. For $P$. spicata, decline in seedling survival was highest between June and the beginning of August. Water limitation was likely the most critical factor responsible for the high seedling mortality in the Reichenberger and Pyke study. Two factors likely influenced the outcomes of the two studies: (1) the long-term, average annual precipitation is higher $(490 \mathrm{~mm})$ at the Green Canyon Experimental Station 
than in Curlew $(305 \mathrm{~mm})$, where the other study was conducted; (2) 1989/1990 were dry years, and 1995/1996 were relatively wet years. However, besides total annual precipitation and the size of individual precipitation events it is ultimately soil water pulses that are available for seedlings that translate precipitation into water usage (Reynolds et al. 2004). The importance of these water pulses (size, frequency, etc.) for seedling establishment, survival, and growth requires further investigation.

Another study indicated that soil water extraction rates of adult plants of the two grass species showed marked differences when interacting with $A r$. tridentata plants, with $A g$. desertorum being a much better competitor for water than P. spicata (Eissenstat \& Caldwell 1988). Seedlings of $A g$. desertorum do not seem to exhibit soil water extraction rates as high as adult plants when interacting with $A r$. tridentata roots, indicating that other forms of interference may be involved (e.g., Callaway et al. 2004). This was shown in the previous study (Reichenberger \& Pyke 1990) and in our study where we observed an early decline in $\mathrm{Ag}$. desertorum seedling survival when interacting with adult $A r$. tridentata.

Although $A r$. tridentata does not appear to decrease seedling survival of the two grass species, root interactions negatively affect mean shoot biomass and height. A lack of early root interference with $A r$. tridentata doubled mean seedling size of $P$. spicata under full light and moderate shade conditions, whereas low light conditions decreased seedling biomass due to limited availability of carbohydrates for root growth and resource uptake (Jackson \& Caldwell 1992). Agropyron desertorum seedlings also were larger when released from early root interference with Ar. tridentata, although different light conditions did not indicate clear effects on seedling biomass. For long-term seedling survival, it is important to examine seedling size and thus the size distribution of seedling populations, because the likelihood for survival of a few yet vigorous seedlings may be substantially higher than for a larger number of relatively small seedlings (Schwinning 1996). However, these are predictions, which should be tested in long-term studies. Overall, the size variability was high in all seedling populations for both grass species, suggesting that a few large individuals occurred in all light and root interaction treatments. Pseudoroegneria spicata seedling populations had more pronounced size variability (high $\mathrm{CV}$ ) in the early root-exclusion treatments, whereas $A g$. desertorum seedling populations had overall a very high $\mathrm{CV}$. The largest $P$. spicata seedlings occurred in early root-exclusion treatments, whereas the size of the largest $\mathrm{Ag}$. desertorum seedlings did not depend on early root exclusion from Ar. tridentata.

Although in semiarid and arid environments, soil nutrient concentrations beneath shrub canopies are generally much higher than in interspaces due to the "island of fertility" effect, the spatial distribution of soil organic matter and soil-extractable phosphorous and potassium may show high spatial variability beneath $A r$. tridentata shrubs
(Jackson \& Caldwell 1993). Although the shrubs in our study were only 5 years old and hence the island of fertility effect not as apparent, the few big seedlings may have been successful in garnering those soil resources; however, further studies will be needed to verify this assertion.

Most revegetation and restoration techniques for arid and semiarid rangelands require removal of woody vegetation before reintroducing the herbaceous components of the community. Our results indicate that reintroducing the herbaceous plants before reducing the abundance of the woody plants may be feasible and warrants further investigation. We did not detect marked differences between the two species in establishment, survival, or growth. Thus, the native $P$. spicata appears as suitable for restoration purposes as the introduced $A g$. desertorum. Our results also indicate that when using $P$. spicata seeds for restoration purposes in dense $A r$. tridentata stands, the light conditions should not affect seedling establishment and growth either positively or negatively unless light reduction is strong (70-90\%). Thus, seeding on south sides of Ar. tridentata is recommended. Because root interaction with $A r$. tridentata decreases mean seedling biomass, preference should be given to seeding in the transition of undershrub canopies and interspaces to minimize root interaction with Ar. tridentata. Thinning of Ar. tridentata stands using prescribed fire (Bunting et al. 1987; Wrobleski \& Kauffman 2003) or selective herbicides (Johnson et al. 1996) 2-3 years after seeding may allow grass seedlings to mature into reproductive adults. This approach should promote the maintenance of a more competitive community, restore species and structural diversity, and thereby restrict the spread of exotic annuals more rapidly than traditional techniques requiring removal of shrubs followed by the application of shrub/grass seed mixtures. Based on this and a previous study (Reichenberger \& Pyke 1990), the success rate of these types of restoration methods can vary significantly from year to year but may be as successful as or more successful than using seed drills in arid environments (Whisenant 2002).

\section{Acknowledgments}

Thanks are due to Michelle Jamison and Stephen Flint for technical assistance in the field. Jeanne Chambers and two anonymous reviewers provided excellent comments on previous drafts of the article. This study was supported in part by the U.S. National Science Foundation (DEB9208212) and the Utah Agricultural Experiment Station, partial funding for D. A. P. came from the USGS Forest \& Rangeland Ecosystem Science Center's Vegetation Diversity Project and the Coordinated Intermountain Restoration Project.

\section{LITERATURE CITED}

Archer, S. 1994. Woody plant encroachment into southwestern grasslands and savannas: rates, patterns and proximate causes. Pages 13-69 in M. Vavra, W. A. Laycock, and R. A. Pieper, editors. Ecological 
implications of livestock herbivory in the West. Society of Range Management, Denver, Colorado.

Archer, S., C. Scifres, C. R. Bassham, and R. Magio. 1988. Autogenic succession in a subtropical savanna: conversion of grassland to thorn woodland. Ecological Monograph 52:111-127.

Bunting, S. C., B. M. Kilgore, and C. L. Bushey. 1987. Guidelines for prescribed burning sagebrush-grass rangelands in the northern Great Basin. General Technical Report INT-231. U.S. Department of Agriculture, Forest Service, Intermountain Research Station, Ogden, Utah.

Caldwell, M. M. 1990. Water parasitism stemming from hydraulic lift: a quantitative test in the field. Israel Journal of Botany 39:395-404.

Caldwell, M. M., T. E. Dawson, and J. H. Richards. 1998. Hydraulic lift: consequences of water efflux from roots of plants. Oecologia 113:151-161.

Caldwell, M. M., D. M. Eissenstat, J. H. Richards, and M. F. Allen. 1985. Competition for phosphorus: differential uptake from dual-isotopelabeled interspaces between shrub and grass. Science 229:384-386.

Caldwell, M. M., J. H. Manwaring, and R. B. Jackson. 1991. Exploitation of phosphate from fertile soil microsites by three Great Basin perennials when in competition. Functional Ecology 5:757-764.

Caldwell, M. M., and J. H. Richards. 1986. Competing root systems: morphology and models of absorption. Pages 251-273 in T. J. Givnish, editor. On the economy of plant form and function. Cambridge University Press, Cambridge, United Kingdom.

Caldwell, M. M., and J. H. Richards. 1989. Hydraulic lift: water efflux from upper roots improves effectiveness of water uptake by deep roots. Oecologia 79:1-5.

Callaway, R. M. 1995. Positive interactions among plants. Botanical Review 61:306-349.

Callaway, R. M., E. H. DeLucia, D. Moore, R. Nowak, and W. H. Schlesinger. 1996. Competition and facilitation: contrasting effects of Artemisia on desert vs. montane pines. Ecology 77:2130-2141.

Callaway, R. M., G. C. Thelen, A. Rodriguez, and W. E. Holben. 2004. Soil biota and exotic plant invasion. Nature 427:731-733.

Campbell, G. S., and G. A. Harris. 1977. Water relations and water use patterns for Artemisia tridentata Nutt. in wet and dry years. Ecology 58:652-659.

Castro, J., R. Zamora, J. A. Hódar, and J. M. Gómez. 2002. The use of shrubs as nurse plants: a new technique for reforestation in Mediterranean mountains. Restoration Ecology 10:297-305.

Castro, J., R. Zamora, J. A. Hódar, J. M. Gómez, and L. Gómez. 2004. Benefits of using shrubs as nurse plants for reforestation in Mediterranean mountains: a 4-year study. Restoration Ecology 12:352-358.

Chambers, J. C., and A. R. Linnerooth. 2001. Restoring riparian meadows currently dominated by Artemisia using alternative state concepts: the establishment component. Journal of Applied Vegetation Science 4:157-166.

Cook, S. J., and D. Ratcliff. 1984. A study of the effects of root and shoot competition on the growth of green panic (Panicum maximum var. trichoglume) seedlings in an existing grassland using root exclusion tubes. Journal of Applied Ecology 21:971-982.

Crawford, J. A., R. A. Olsen, N. E. West, J. C. Mosley, M. A. Schroeder, T. D. Whitson, R. F. Miller, M. A. Gregg, and C. S. Boyd. 2004. Ecology and management of sage-grouse and sage-grouse habitat. Journal of Range Management 57:2-19.

Dawson, T. E. 1996. Determining water use by trees and forests from isotopic, energy balance and transpiration analysis: the roles of tree size and hydraulic lift. Tree Physiology 16:263-272.

Doescher, P. S., R. E. Miller, and A. H. Winward 1984. Soil chemical patterns under eastern Oregon plant communities dominated by big sagebrush. Soil Science Society of Americal Journal 48:659-663.

Eissenstat, D. M., and M. M. Caldwell. 1988. Competitive ability is linked to rates of water extraction. Oecologia 75:1-7.

Fox, G. A. 2001. Failure-time analysis: emergence, flowering, survivorship, and other waiting times. Pages $235-267$ in S. M. Scheiner, and
J. Gurevitch, editors. Design and analysis of ecological experiments. Oxford University Press, New York.

Garcia-Moya, E., and C. M. McKell. 1970. Contribution of shrubs to the nitrogen economy of a desert-wash plant community. Ecology 51:81-88.

Heady, H. F. 1988. The Vale rangeland rehabilitation program: an evaluation. U.S. Forest Service Pacific Northwest Station and U.S. Department of the Interior, Bureau of Land Management PNW-RB-157, Portland, Oregon.

Jackson, R. B., and M. M. Caldwell. 1992. Shading and the capture of localized soil nutrients: nutrient contents, carbohydrates, and root uptake kinetics of a perennial tussock grass. Oecologia 91:457-462.

Jackson, R. B., and M. M. Caldwell. 1993. Geostatistical patterns of soil heterogeneity around individual perennial plants. Journal of Ecology 81:683-692.

Johnson, K. H., R. A. Olson, and T. D. Whitson. 1996. Composition and diversity of plant and small mammal communities in tebuthiurontreated big sagebrush (Artemisia tridentata). Weed Technology 10:404-416.

Knick, S. T., D. S. Dobkin, J. T. Rotenberry, M. A. Schroeder, W. M. Van der Haegen, and C. Van Riper III. 2003. Teetering on the edge or too late? Conservation and research issues for avifauna of sagebrush habitats. Condor 105:611-634.

McArthur, E. D., B. L. Welch, and S. C. Sanderson. 1988. Natural and artificial hybridization between big sagebrush (Artemisia tridentata) subspecies. Journal of Heredity 79:268-276.

Miller, R. F., T. J. Svejcar, and N. E. West. 1994. Implications of livestock grazing in the intermountain sagebrush region: plant composition. Pages 101-146 in M. Vavra, W. A. Laycock, and R. D. Pieper, editors. Ecological implications of livestock herbivory in the west. Society for Range Management, Denver, Colorado.

Pyke, D. A. 1990. Comparative demography of co-occurring introduced and native tussock grasses: persistence and potential expansion. Oecologia 82:537-543.

Reichenberger, G., and D. A. Pyke. 1990. Impact of early root exclusion on fitness components of four semiarid species. Oecologia 85:159-166.

Reynolds, J. F., P. R. Kemp, K. Ogle, and R. J. Fernandez. 2004. Modifying the "pulse-reserve" paradigm for deserts of North America: precipitation pulses, soil water, and plant responses. Oecologia 141:194-210.

Robertson, J. H. 1971. Changes on a sagebrush-grass range in Nevada ungrazed for 30 years. Journal of Range Management 24:397-400.

Salihi, D. and B. E. Norton. 1987. Survival of perennial grass seedlings under intensive grazing in semiarid rangelands. Journal of Applied Ecology 24:145-153.

Schwinning, S. 1996. Decomposition analysis of competitive and size structure dynamics. Annals of Botany 77:47-57.

Sanders, K. D., and A. S. Voth. 1983. Ecological changes of grazed and ungrazed plant communities. Pages 176-179. Managing intermountain rangelands-improvement of range and wildlife habitats. U.S. Forest Service General Technical Report INT-157. U.S. Forest Service, Washington.

SAS. 1996. SAS/STAT user's guide. Release 6.12. SAS Institute, Cary, North Carolina.

Schlesinger, W. H., J. F. Reynolds, G. L. Cunningham, L. F. Huenneke, and W. M. Jarrell. 1990. Biological feedbacks in global desertification. Science 247:1043-1048.

Stoddart, L. A. 1946. Some physical and chemical responses of Ag. desertorum spicatum to herbage removal at various seasons. Utah State University Agricultural Experimental Station Bulletin 324:24.

Vallentine, J. F. 1989. Range development and improvements. Academic Press, San Diego, California.

Van Auken, O. W. 2000. Shrub invasion of North American semiarid grasslands. Annual Review in Ecology and Systematics 31:197-215. 
West, N. E. 1983. Western intermountain sagebrush steppe. Pages 351374 in N. E. West, editor. Temperate deserts and semi-deserts. Elsevier Scientific, Amsterdam, The Netherlands.

West, N. E. 1991. Intermountain deserts, shrub steppes, and woodlands. Pages 209-230 in M. G. Barbour and W. D. Billings, editors. North American terrestrial vegetation. Cambridge University Press, New York.

West, N. E., F. D. Provenza, P. S. Johnson, and M. K. Owens. 1984. Vegetation change after 13 years of livestock grazing exclusion on sagebrush semidesert in west central Utah. Journal of Range Management 37:262-264.
Whisenant, S. G. 2002. Manipulating the physical environment in terrestrial systems. Pages 83-105 in M. Perrow and T. Davy, editors. Ecological restoration handbook, Volume 1. Principles of restoration. Cambridge University Press, Cambridge, United Kingdom.

Wrobleski, D. W., and J. B. Kauffman. 2003. Initial effects of prescribed fire on morphology, abundance, and phenology of forbs in big sagebrush communities in southeastern Oregon. Restoration Ecology 11:82-90.

Young, J. A., R. A. Evans, and J. Major. 1977. Sagebrush steppe. Pages 763-796 in M. G. Barbour, and J. Major, editors. Terrestrial vegetation of California. Wiley, New York. 